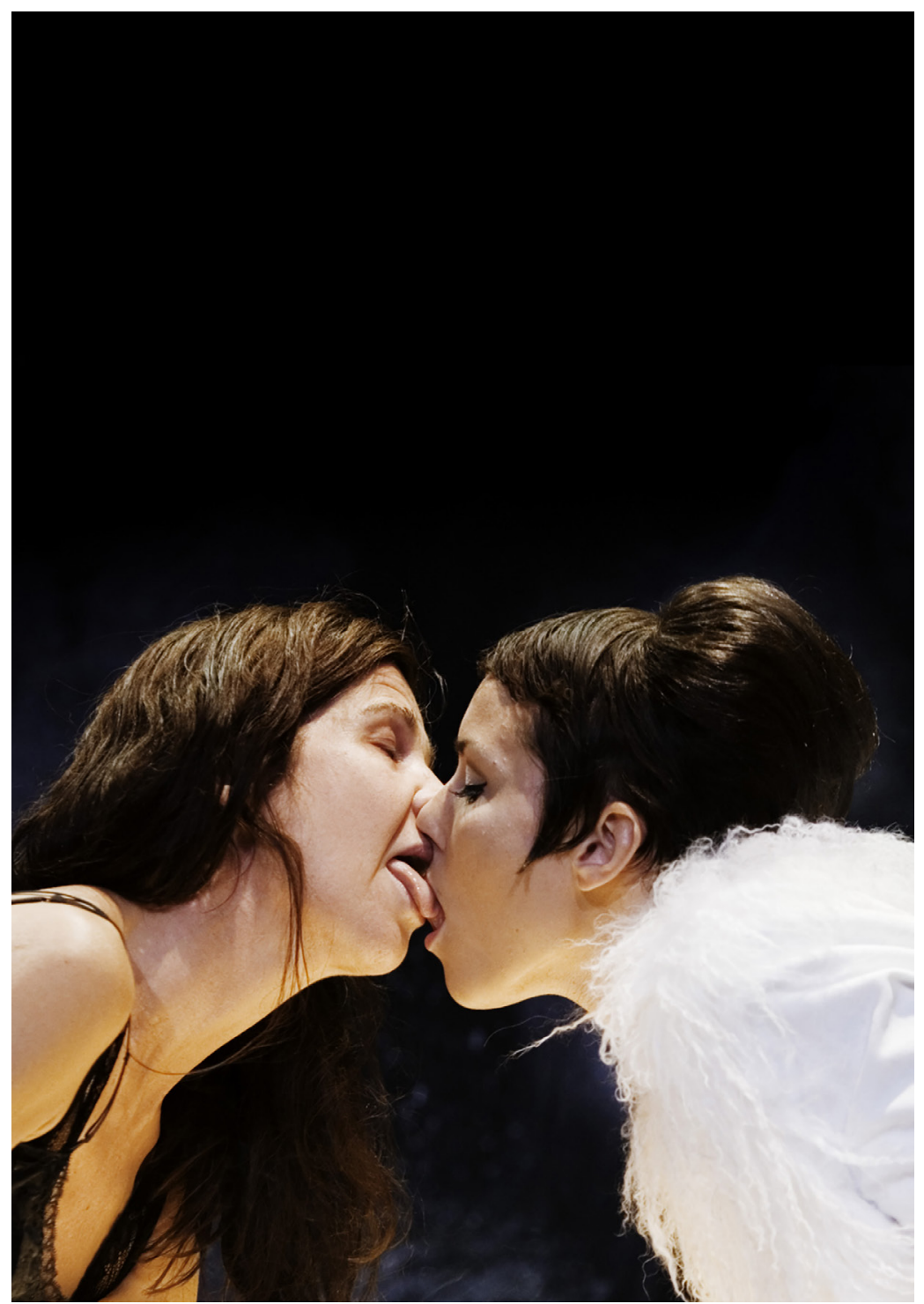

Valerie Solanas for President of the United States (Sara Stridsberg). Ingela Olsson (Valerie Solanas) and Noomi Rapace (Cosmogirl). Royal Dramatic Theatre, Stockholm, 2006. Photographer: Roger Stenberg. Copyright CCBY-NC-ND, Royal Dramatic Theatre, Stockholm. 


\section{Still Angry After All These Years, or Valerie Solanas Under Your Skin}

Every man, deep down, knows he's a piece of shit. -Valerie Solanas, S.C.U.M. Manifesto

On April 30, I988, the body of Valerie Solanas was found at the Bristol Hotel, a single-room occupancy in the Tenderloin District of San Francisco. According to the terse police report she was kneeling beside the bed in the tidy room with papers carefully arranged on her desk. The report goes on to state that Solanas had died around April 25 and that cadaverous worms had invaded her body. The hotel staff had seen her writing at her desk a few weeks earlier.

The image of the neat room with piles of manuscripts and the dead body of Solanas fascinated Sara Stridsberg, a Swedish playwright and novelist. She decided to find out who Solanas was, just as Isabelle Collin Dufresne, one of Andy Warhol's superstars, had done almost two decades earlier. In the I960s, Dufresne, better known as Ultra Violet, had phoned people who knew Solanas. By the time Solanas died only a few of them were still alive. They had warned Ultra Violet about Solanas. She is dangerous, they said. ${ }^{\mathrm{I}}$

Stridsberg was intrigued by everything she found out. Solanas literally got under her skin. Stridsberg's novel, The Dream Faculty: An Addition to the Theory of Sexuality (2006) and her play Valerie Jean Solanas for President of the United States (2006) both center around Solanas. Characteristic for Stridsberg's work are her heroines, whom she depicts in a vulnerable and deplorable state, although they continue to maintain their dignity. Stridsberg's play tells of Solanas's wounded childhood, how she sold her body to finance her studies in psychology, why she shot Andy Warhol, and

\section{How to cite this book chapter:}

Rosenberg, Tiina 20I6. Still Angry After All These Years, or Valerie Solanas Under Your Skin. In: Rosenberg, Tiina Don't Be Quiet, Start a Riot! Essays on Feminism and Performance. Pp. I76-1 82. Stockholm: Stockholm University Press. DOI: http://dx.doi.org/Io.I6993/baf.i. License: CC-BY 4.0 
about her death in the hotel room in San Francisco. The playwright also translated Solanas's S.C.U.M. Manifesto from English into Swedish in 2003 and provided the text with an extensive introduction. The acronym S.C.U.M. stands for Society of Cutting Up Men, a fictitious organization whose founder and sole member was Solanas. The original Swedish version of the S.C.U.M. Manifesto was performed in Stockholm in 2003 , staged as a chorus of angry women reciting it like an act of political agitation.

Stridsberg knew the S.C.U.M. Manifesto by heart. She had laughed and cried over this irresistible wild and crazy satire of patriarchy that resembled nothing a feminist had ever written before. The language of the manifesto is harsh and its ideals completely beyond reach. Its intense tone does not belong to any school of rhetoric, politics, art, or philosophy. It is a fantastically desperate and euphorically mad text. Stridsberg believes that the S.C.U.M. Manifesto is all about poetry, not politics in the traditional sense. She places Solanas in the same company as Sylvia Plath, Courtney Love, Gertrude Stein, Yoko Ono, Billie Holiday, and Tracey Emin.

Writing about Solanas was Stridsberg's attempt to communicate with the woman whose turbulent life had produced the most outlandish utopia ever. Stridsberg describes Solanas's childhood as a dance macabre of violence and brutality, and her end as the contrast between the frenzied voice of the manifesto and a lonely death in a cheap hotel room. Solanas's complicated life embraced things we are used to regarding as incompatible. Stridsberg finds her "the intellectual whore, the utopian misanthrope. She is the victim who refuses to excuse herself. She is the child without childhood; she is the women's movement without women. She is the absolute triumph and the definitive defeat." 2 Stridsberg was also determined to find out why Solanas, the anti-violence activist, would shoot Andy Warhol. Those attending Stridsberg's play received no answer to that question; they only learned that Solanas regretted she had not been a better shot.

The real Valerie Solanas (I936-I988) was born in Ventnor City, New Jersey. Very little is known about her life until I966 when she moved to Greenwich Village and published the play Up Your Ass. It featured a man-hating heroine who managed to survive as a sex worker and beggar, as Solanas had done. Andy Warhol liked Up Your Ass and they began to socialize. In I967 Solanas 
wrote the S.C.U.M. Manifesto. Then, one year later, she suddenly shot Andy Warhol. There are many interpretations of her action. Some have seen it as a feminist attack on Warhol as the master vampire of the arts. This is how the story is told in the film I Shot Andy Warhol (1996), which presents Solanas as a feminist heroine. After Solanas was released from jail in I97I, her reputation oscillated between feminist martyr and madwoman. During the times when she was not hospitalized, she lived alone in run-down hotels and spent her time writing.

As Stridsberg mulled over the piles of papers and manuscripts on Solanas's desk in her imagination, a dream play began to emerge. In this play she saw Solanas as a brilliant but confused bag lady dressed in a silver coat. As the play Valerie Jean Solanas for President of the United States opens, Valerie is dying in a hotel room. Now and then she rises from her deathbed and enacts dream sequences, hallucinations, and scenes from her life. Valerie is the driving force of the play. She appears before us as its explosive element, while the other characters are merely pale figures. Valerie is depicted as standing against the world, pushing beyond all limits. She moves rapidly from the hopeful young student to the drug-addicted street person. She talks nonstop; her genre is monologue and her tempo furioso. Whether we see her in prison or in a mental institution, she is hysterically repeating her mantra that men are superfluous and inferior to women in every respect. In one ultra-rapid discourse Valerie appears to be fleeing from a pursuer. Her words function as both a weapon and music.

Stridsberg's interest in Solanas may be viewed in the context of the socially committed Swedish theatre of the I990s and early 2000 , although the political performing arts scene in Sweden has links back to earlier decades. Taking an open political stand on gender, sexuality, ethnicity, class, and other social issues were hot topics in the Swedish theatre during the late I990s, but the most pressing issue was and remains today the downscaling of the Swedish welfare state. Leftist feminists felt that the world-renowned Swedish project of a social democratic, egalitarian, and open society had changed beyond recognition. ${ }^{3}$

The public reading of the S.C.U.M. Manifesto was strongly challenged by men, who saw neither the irony of the text nor what the point of such an event was altogether. The historical context in 
which the performance took place was significant: all the political parties in Sweden, with the exception of the Conservatives and Christian Democrats, had declared themselves feminist parties. At this moment of presumed feminist consensus, the S.C.U.M. Manifesto resounded like a declaration of war. Sweden was a country in which pragmatic gender equality politics could not afford to have angry lesbian feminists making explicit proclamations in a public space, or anywhere else for that matter.

Looking back on that time, it becomes clear that what took place was a political misunderstanding in which mainstream gender equality politics were taken for feminism. The price of mainstreaming is always a certain degree of adjustment to hegemony. Feminism occupied a paradoxical position in the early 2000s; it was at once integral to hegemonic gender equality politics, and at the same time marginal, feared, and ridiculed. It had become a victim of its own success. A bored bourgeoisie picked out the parts of feminist and leftist subculture that they found amusing, consumed it, but did not "buy" it.

This was the moment when feminist artists turned to revolutionaries like Valerie Solanas or Ulrike Meinhof, rather than looking to mainstream politics for support. Stridsberg reveled in a figure who could never become mainstream: the angry lesbian feminist. There is no social space that such a character may inhabit. Stridsberg's main concern was resistance, as Meinhof had succinctly defined the term in her 1967 article "From Protest to Resistance" in the journal konkret. "Protest," Meinhof wrote, "is when you say that something does not suit you. Resistance is when you see to it that the thing not suiting you stops." 4 The logic here is that there is not necessarily anything wrong with angry women, but there is something wrong with a heterosexist world. Angry women are generally not well received, but the history of anger gives feminist politics its edge. Anger is a form of 'against-ness' akin to the way Meinhof defines resistance. It is not only a sign of protest, but seeks to put an end to the thing you are protesting against.

Valerie Solanas is not easy to shake off. "She is a state of mind," Stridsberg writes, "a play, an invasion, a mirror, a wonderland, and a promise of absolutely nothing. Her heart becomes an insatiable pulsating wound. Valerie is both a utopist and a romantic." 5 
Stridsberg has entitled her play Valerie Jean Solanas for President of the United States because she envisions a black utopia. She addresses life and death, expressing, in Jill Dolan's words, “a rather melancholic yearning for a different future, fueled by wistful but persistent hope." ${ }^{6}$ Dolan terms this militant optimism.

Stridsberg's play and novel are her postmortem gifts to Solanas, the fulfillment of a wish to give her everything she failed to obtain when alive: an army of lovers in silver coats, her life as a dream and a nightmare. Stridsberg has written that she never loved any text as much as she did the S.C.U.M. Manifesto. "It has changed my way of thinking, my heart, and my cunt, my way of moving through the city; it has taught me everything worth knowing."7 Stridsberg writes that the Manifesto is impossible to forget once you have read and absorbed it. Patriarchy has every reason to be fearful of it because it is a dangerous text. Clarity (the text forces you to see) and mercilessness (the text has no loyalty to men) are its gift to the reader. When Solanas was a little girl her father raped her. She later lived for a long time as a sex worker. The street is the loneliest place in the world and it is the heart of patriarchy: "a puffing, screaming, black hole of misogyny and sticky bodily fluids. S.C.U.M. is written of that experience. What is said about patriarchy from that position is the only thing that is worth knowing about patriarchy."

In creating the Valerie character Stridsberg takes Solanas seriously and also demonstrates her own retrospective solidarity with the author. Valerie is the kind of person we have all seen begging on the street, talking to themselves, frightening passers-by. You can recognize a Valerie lookalike by her worn-out coat and bag full of unassorted curiosities. Lipstick may be smeared on her face and she may be carrying on an endless conversation with herself on all kinds of topics. If you stop for a moment and listen to what such a person is saying, you may hear anything from hardcore poetry to absolute nonsense to brilliant political analysis. It may be incomprehensible but also extraordinarily beautiful, and may range from obscure to crystal clear. "Everything is made up and poetry makes it obvious," Stridsberg says about the Manifesto. ${ }^{9}$ It is a text without compromises. "This is an agenda for eternity and utopia," Stridsberg concludes, as she reminds her readers that, "It is now or never. The future is S.C.U.M. The future is already here." 


\section{Notes}

I. Violet, Famous for I5 Minutes.

2. Stridsberg,"Den svarta utopin."

3. Rosenberg, “Revival," 4I3.

4. Meinhof, "Von Protest zum Widerstand.” For a comprehensive list of Meinhof's publications see: www.jutta-dirfurth.de and www.oekolinx-arl.de

5. Stridsberg, "Den svarta utopin,” I I.

6. Dolan, Utopia in Performance, I42.

7. Stridsberg, "Förord," 7.

8. Ibid., IO-I I.

9. Ibid., I I.

Io. Ibid., 29.

\section{Works Cited}

Dolan, Jill. Utopia in Performance: Finding Hope at the Theatre, Ann Arbor: University of Michigan Press, 2005.

Rosenberg, Tiina. "The Revival of Political and Feminist Performance in Sweden in the 2000s." In Gender Delight. Science, Knowledge, Culture and Writing, edited by Cecilia Åsberg, 4 I I-424. Linköping, Sweden: Linköping University, 2009.

Stridsberg, Sara. Introduction to S.C.U.M. Manifesto by Valerie Solanas. Stockholm: Modernista, 2003.

"Den svarta utopin - anteckningar om en amerikansk superflicka" (The Black Utopia - Notes on an American Super Girl). In Valerie Solanas ska bli president i Amerika, 5-I I. Stockholm: Kungliga Dramatiska teatern, 2006.

Ultra Violet. Famous for I5 Minutes: My Years With Andy Warhol. New York: Harcourt, I988.

Meinhof, Ulrike. “Von Protest zum Widerstand.” Konkret, May I 967. 